\title{
開水路キャビティーせん断層の乱流構造と組織渦の発生機構
}

Turbulent Structure and Generation Mechanism of Coherent Vortex in Cavity Shear Layer of Open-channel Flows

\author{
祥津家久 ${ }^{*}$. 門田章宏 ${ }^{* *} \cdot$ 高津昌夫 ${ }^{* * *} \cdot$ 井上 憲 ${ }^{* * * *}$ \\ By Iehisa NEZU, Akihiro KADOTA, Masao TAKATSU and Ken INOUE
}

\begin{abstract}
Turbulence measurements in and over the cavity of open-channel flows were conducted by making use of a two component fiber-optic laser Doppler anemometer (FLDA). Mean Structures in the cavity shear layer were examined in detail and it was revealed that the turbulent structures depended on the length of cavity significantly.

The visualization of coherent vortices was carried out by the use of dye injection techniques, and the characteristics of coherent and unstable vortices around separation point were clarified by means of unstable analysis. The fundamental frequency was determined and unstability of coherent vortices was examined.
\end{abstract}

Keywords : cavity flow, visualization, coherent vortices, unstable analysis, fundamental frequency

1.はじめに

実際の河川においては，河床波，蛇行などの自然的な要因や，堰，ゲート，トレンチなどの人工的な要因 によって不連続な境界が形成される. そのなかでもトレンチは流送土砂制御の目的で設置されているだけで はなく，多自然型河川工法の一つとして設置され，「瀬・淵」の水工設計に必要となる．また，これに類似 する流れ場を形成するワンドも，環境にやさしいという観点から，近年非常に注目されている，一方，水理 学的にみても, 開水路キャビティー流れは, 剥離せん断層の発達, 組織渦の発生・発達・崩壊, あるいは逆 流域, 死水域の存在といったような複雑な乱流場を形成し，非常に興味深い局所流となる.

Knisely \& Rockwell(1982)1)は，下流衝突端のあるキャビティー流れにおいてLDAを用いた乱流計測ととも に, 水素気泡法により組織渦の可視化を行った. その結果, キャビティー上流端から発生する剥離渦が下流 端に衝突する位置は規則的に変化することを指摘した。八木 $(1984)^{2)}$ は, 染料注入法を用いて可視化実験を行 い, 組織渦の不安定性について検証した. 彼は, 凹部上流端で剥離した流れによって形成される不安定波の ピーク周波数が, 主流速, 凹部長さ, せん断層の厚さによって変化することを指摘した. 最近では, 藤田ら

* 正会員 工博 京都大学工学部助教授 環境地球工学教室

( \% 606 京都市左京区吉田本町)

** 学生員 工修 京都大学大学院 土木工学専攻

*** 学生員京都大学大学院 環境地球工学専攻

*****学生員京都大学工学部 土木工学科 
$(1994)^{3)}$ が, 濃淡画像相関法(PIV)を用いた画像処理により，キャビティー内部の二次元流速場を計測するとと もに, LESによる数值計算によってキャビティー内部の流速場を再現することを試みている.

以上のように, 従来の研究により, 組織構造がいくらか解明されつつあるが, 凹部の形状比や流量を系統 的に変化させていろいろな統計量を取り扱っているものは少ない，そこで本研究では染料を用いた可視化実 験と, ファイバーレーザー流速計(FLDA)による乱流計測を行い, 平均流特性, 乱れ特性等について検討し, キャビティー端部から発生する組織渦の不安定性について考察する.

\section{2. 実験装置および実験方法}

本実験で使用した水路は, 長さ $10 \mathrm{~m}$, 幅 $50 \mathrm{~cm}$ ，側壁高さ $56 \mathrm{~cm}$ の直線水路である. キャビティーの凹部形状は, 全面にわたって ペンキ塗りされた鉄板を角材により底上げす ることにより作成した，凹部の幅は自由に変 化させることができる：水路上流部においては流路床を滑 らかな曲線に沿って傾斜させてキャビティ一高さまで滑ら かに変化させた．なお，キャビティーは水路上流端より $5 \mathrm{~m}$ の位置に設置した。

実験装置の概要を図-1(a), 図-1(b)に示す。可視化実験装 置は染料タンク, ビニールチューブ, ガラスコックおよび 染料を流す注射針からなる. 注射針は水路横断方向に平行 に二本設置した．染料にはローダミンB(赤)を用いた，可視

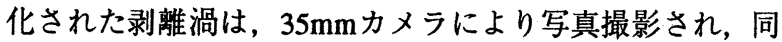
時にビデオカメラによっても撮影されている. 次に可視化 による実験結果をもとに, 剥離渦の発生する界面付近の領 域を中心に, ファイバーレーザー流速計(DANTEC社製)に よる乱流計測を行った。

実験条件を表-1に示す．测定断面はキャビ ティー端部より上流部2断面, キャビティー 内部に5から9断面, それより下流部で2から3 断面であり，測定点は合計220から340点であ ๖.

\section{3. 実験結果および考察}

\section{1 平均流速および乱れ強度}

図-2にキャビティー内部における平均流速 $U$, 乱れ強度 $u^{\prime}, v^{\prime}$, レイノルズ応力 $-\overline{u v}$ の鉛

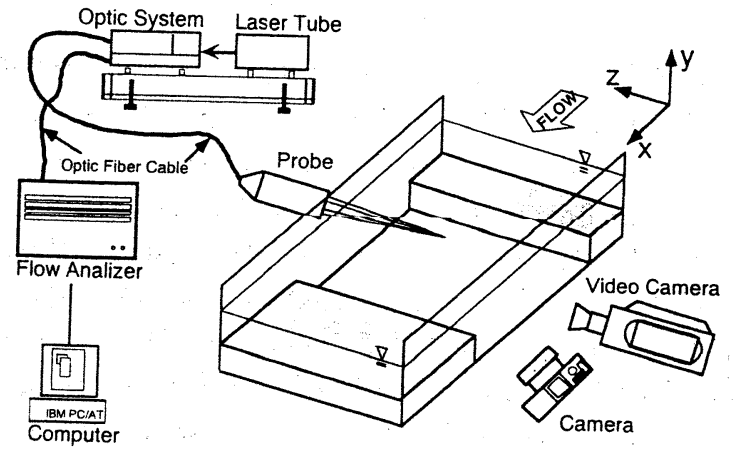

図-1 (b) 実験装置(点計測，画像撮影)

直方向分布を示す．それぞれについてキャビティー初期断面 $x=0$ における最大流速 $U_{\max 0}$ で無次元化してある. 平均流速Uについては, キャビティー内部上流側の界面近くで発生した逆流が下流の底面方向に広がっていく 様子がわかる. しかし，段落ち流れ4)でみられるような再付着点は，全ケースを通して観察されなかった。 キャビティー部上方では平均流速分布は対数則型の分布を示しており，これに対応してレイノルズ応力分布 も三角形分布を示している．レイノルズ応力，乱れ強度分布についてケース間で比較すると，L/H=3.0のとき が最も大きくなっており，あるキャビティ一長さLにおいて乱れが増幅されていることがわかる，これは，八 木(1984)も指摘しているように，キャビティー上流端からの剥離渦の発生周期があるキャビティー長さLにお いて高い值にジャンプするためで，この現象は水面変動と不安定波との共鳴現象で起こると考えられ，今後 詳細に検討したい. 

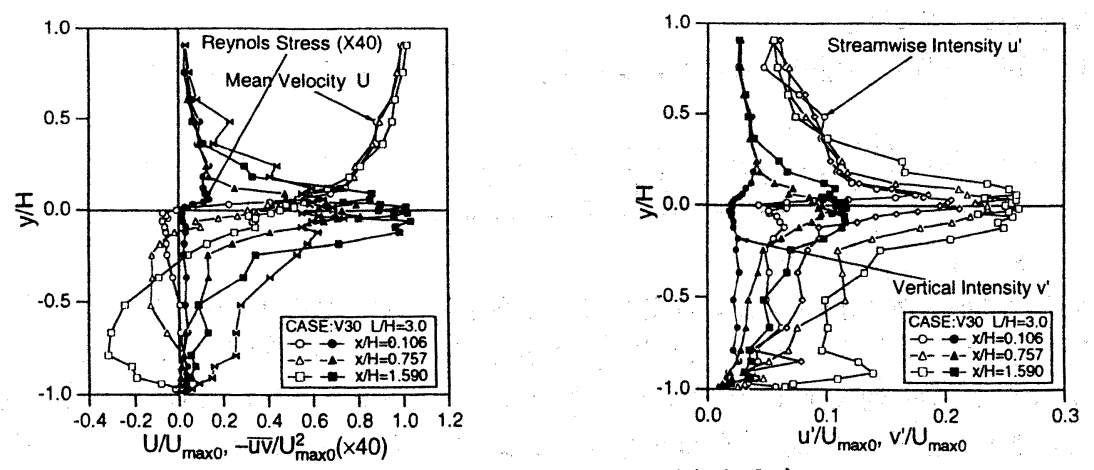

図-2 (a) 平均流速，乱れ強度，レイノルズ応力分布 (Q25V30h66)
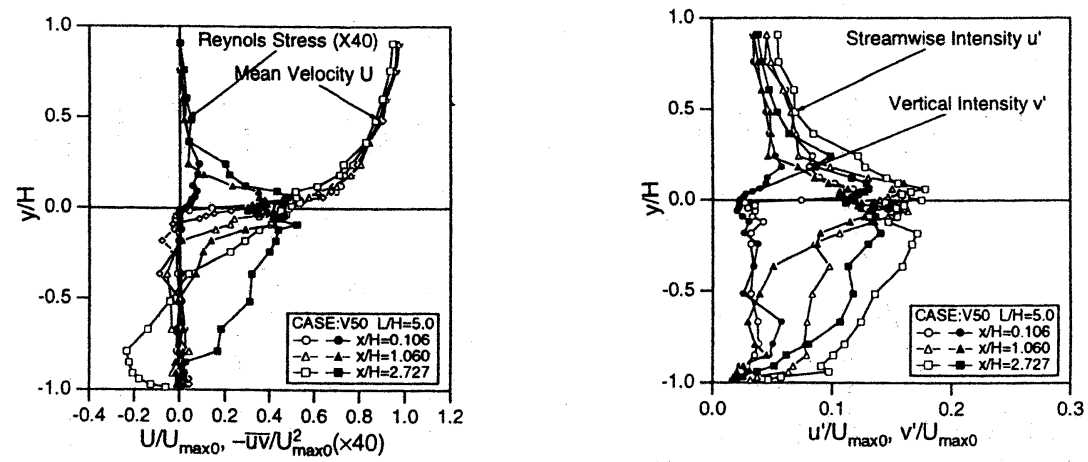

図-2 (b) 平均流速, 乱れ強度，レイノルズ応力分布 (Q25V50h66)

\section{2 圧力分布特性}

圧力は鉛直二次元乱流場の運動方程式を積分するこ とにより，以下のように求められる.

$$
\begin{aligned}
& P / \rho=g(h-y) \cos \theta+\Delta P / \rho \\
& \Delta P / \rho=\int_{y}^{h} \frac{\partial(U V+\overline{u v})}{\partial x} d y+\left[V^{2}+\overline{v^{2}}\right]_{y}^{h}
\end{aligned}
$$

ここで $\theta$ は水路勾配, $g(h-y) \cos \theta$ は静水圧分布, $\Delta P$ は変動流速による動圧分布である．図-3は動圧力分布 のコンターである. $\Delta P$ は $\rho U^{2}{ }_{\text {max }} / 2$ で無次元化してあ る.キャビティー下流端壁面付近で正圧となってお り，段落ち流れと比較して，より複雑な分布を示して いる. 図-4は壁面圧力係数 $C_{p}=2\left(P-P_{0}\right) / \rho U_{\text {max }}^{2}$ の流 下方向分布を示したものである． $P_{0}$ は初期断面での底 面圧力である。図中には，中川・鿅津(1987)による段 落ち流れのデー夕を併せて示してある。キャビティー 下流端においてCpは急激に增加しており，キャビ ティー下流底面付近において大きな動圧 $\Delta P$ が発生し ていることに対応している。

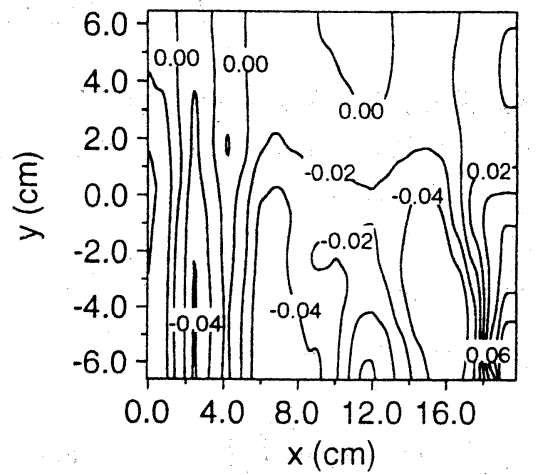

図-3 動圧力分布のコンター

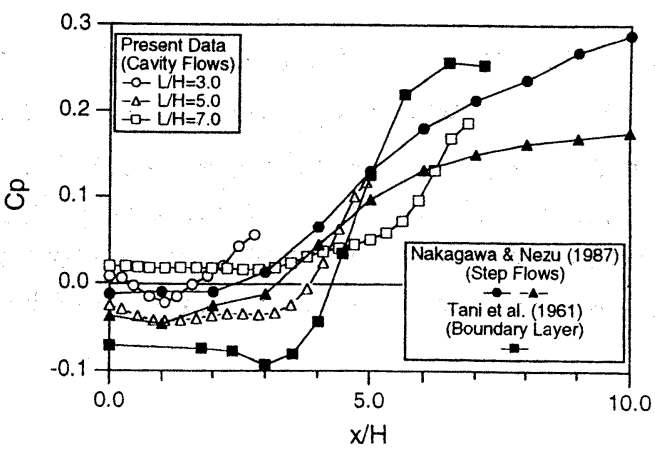

図-4，壁面圧力係数 


\section{3 世ん断応力の分布特性}

せん断応力は, 運動方程式を積分することによって, 以下のように求められる.

$$
\frac{\tau}{\rho}=-\overline{u v}+v \frac{d U}{d y}=g I_{e}(h-y)-\int_{y}^{h} \frac{\partial U^{2}}{\partial x} d y-[U V]_{y}^{h}-\int_{y}^{h} \frac{\partial}{\partial x}\left(\frac{\Delta P}{\rho}+\overline{u^{2}}\right) d y
$$

$$
=G+M_{1}+M_{2}+P U
$$

ここで $M_{1} M_{2}$ は運動量項, PUは動庄力および乱れによる寄与を表す. 図-5は, せん断応力分布への各項の寄 与を比較検討したものである. 重力項Gが流下方向に大きく変動しており支配的である. また，キャビティー

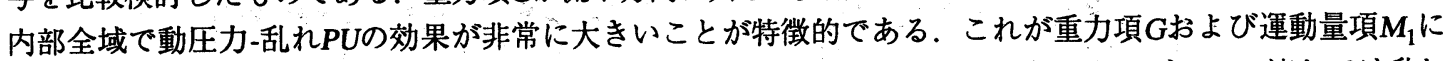
よってキャンセルされ, 全せん断応力自体は小さな值となっている. 以上より, キャビティー流れでは乱れ の効果が極めて重要であることがわかる.
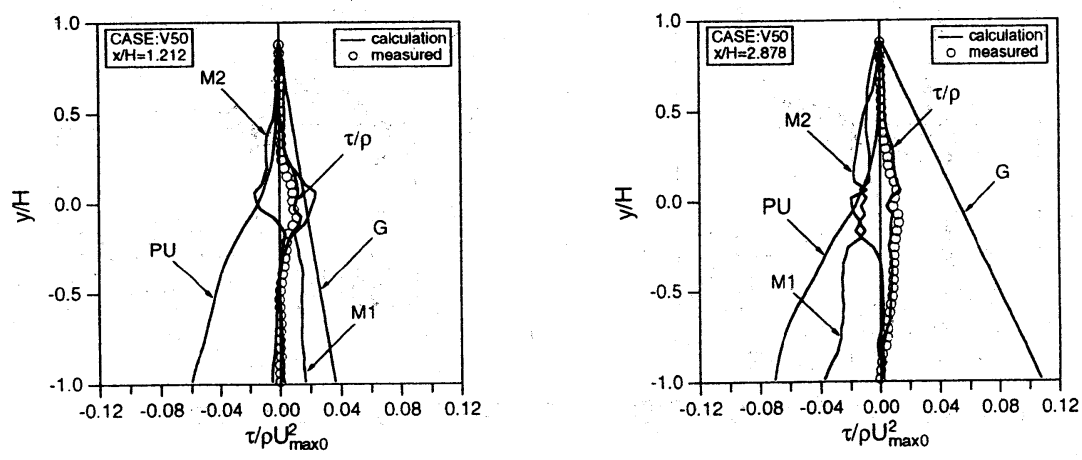

図-5 せん断応力の内部棧造(Q25V50h66)

\section{4 運動量およびエネルギーの変換過程}

運動量および平均エネルギーに関する保存式は，式(3)をガウスの発散定理を用いて体積積分することに よって以下のように求められる.

$[M]_{1}^{2}=$ Volume $\cdot g \cdot \sin \theta-\int_{1}^{2} \frac{\tau_{0}}{\rho} d x, \quad M=\int_{-H}^{h}\left(U^{2}+\overline{u^{2}}\right) d y+\frac{g}{2} h^{2} \cos \theta$

$[H]_{1}^{2}=\frac{1}{g U_{m} h}\left\{\iint G e n \cdot d x d y+\left[\int_{-H}^{h}\left(\left(\overline{u^{2}}-\overline{v^{2}}\right) U+\overline{u v V}\right) d y\right]_{1}^{2}\right\}=0, \quad H=\frac{\alpha U_{m}^{2}}{2 g}+h \cos \theta$

ここでGenは乱れの発生項である. 図-6，図-7にそれぞれ式(4)，(5)の保存関係を示す．図では水深変化が明 瞭となるように, $M^{\prime} \equiv M-\left(g h_{1} \cos \theta\right) / 2, H^{\prime} \equiv H-h_{1} \cos \theta$ としている. 図中には段落ち流れのデータも併せて 示されているが, これと比較すると運動量の減少は非常に小さくなっている.これは, 開水路キャビティー 流れでは，キャビティーより上方の領域では平均流速分布が流下方向にほとんど変化しないこと，キャビ ティー内部における平均流速が小さく流下方向変化があまり大きくないことに起因すると思われる.一方, 平均エネルギーについては, 段落ち流れと同様の傾向がみられる. 


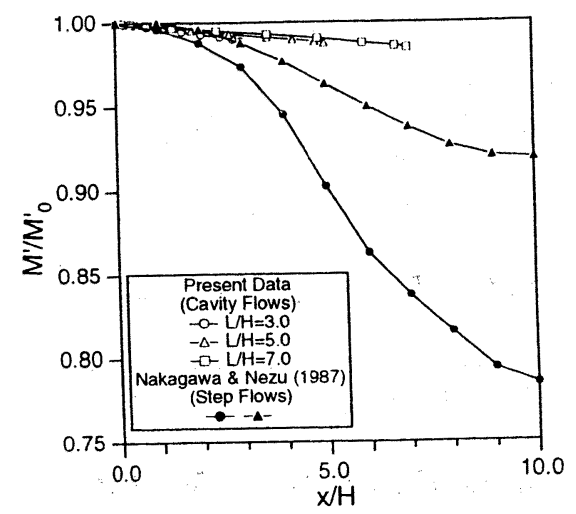

図-6 運動量保存関係

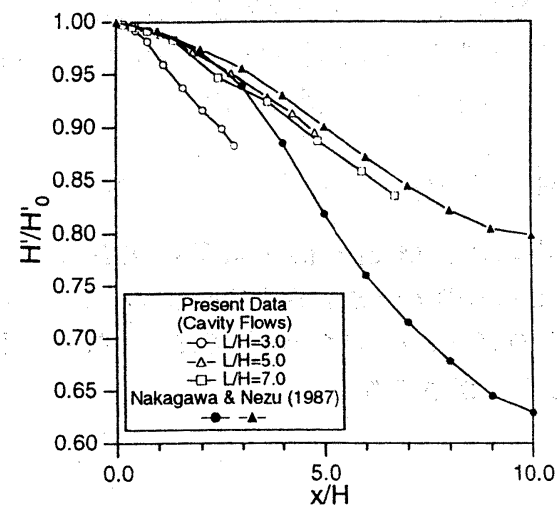

図-7 平均エネルギー保存関係

\section{5 凹部界面の不安定性}

図-8は，キャビティー上流端から発 生する剥離渦を染料注入法によっで可 視化したものを，35mmカメラで撮影 した写真である.キャビティー上流端 から発生した剥離渦の様子が観察され る。

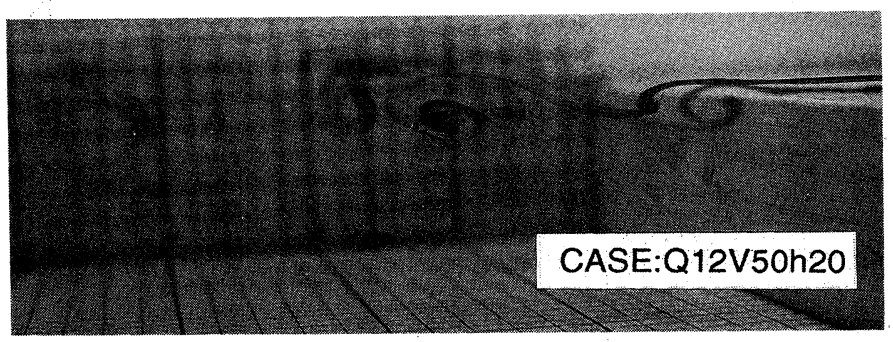

図-8 剥離渦の様子

凹部界面の上流端において剥離した 境界層は, 固有の周波数, 波数をもつ

不安定波を形成する。この周波数祀基本周波数と呼ぶ. 本実験において は，可視化映像による情報，FLDAによるデー夕から総合的に基本周波数 を評価した．図-9は変動流速山のスペクトルを，図-10は変動流速uの自己 相関係数の変化を示したものである.これらをもとに評価した基本周波数 fとフルード数との関係を示したものが図-11である，以下の図において $\theta_{0}$ は初期断面における運動量厚さであり，

$\theta_{0}=\int_{-\infty}^{\infty} \frac{u}{U}\left(1-\frac{u}{U}\right) d y$

で定義される，Uは各断面における平均流速の最大值である．またこの図 中には八木のデー夕も併せて示している，八木のデータによると，水理条 件によらず $\theta_{0} / U$ 值はほほ一定の值をとっているが, 本実験においては そのようなはっきりとした傾向は現われていない，図-12、図-13は凹部界 面の不安定波の波長入および位相速度Ucをビデ オカメラにより実測した値を示している．図に はMichalkes)の計算結果および八木のデータも示 したが，本実験で得られたデー夕はこれらの值 と必ずしも一致していない。そそれは本実験での 剥離点付近の流速分布が以下の式

$\hat{U}=0.5\left(1+\tanh \frac{y}{L}\right)$

で示されるMichalkeの仮定に一致していないと ころに起因する可能性がある．図-14に賣乱の空

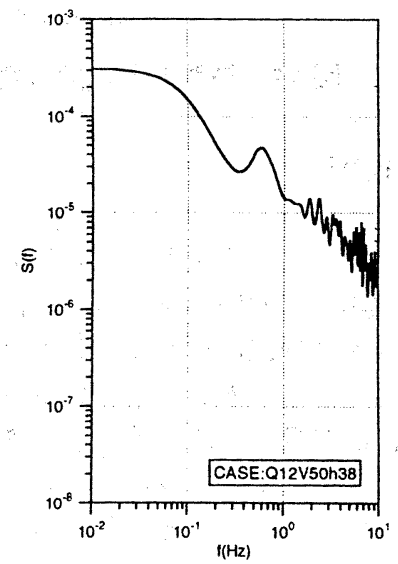

図-9＼cjkstart変動流速 uのスペクトル分布

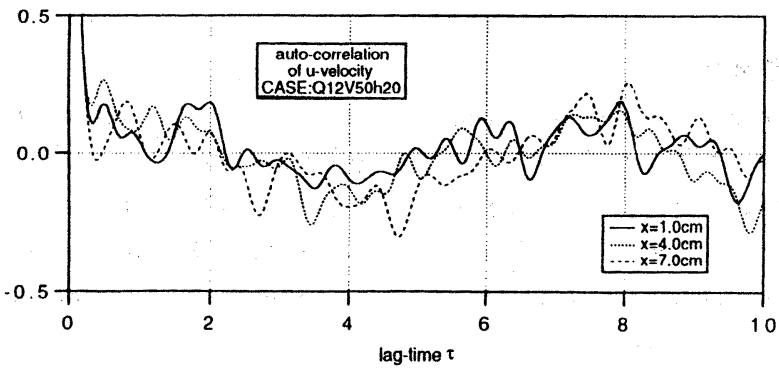

図-10 変動流速 $u$ の自己相関係数 
間的成長率を示す. 擾乱の空間的成長率- $\alpha_{i}$ は, 瞬間 流速のスペクトルから基本周波数成分 $u_{\mathrm{f}}$ の流下方向変 化を算定し，以下の式から計算した22).

$$
-\alpha_{i}=\frac{d}{d x} \ln \left(\sqrt{u_{f}^{2}} / U\right)
$$

この図中には, Michalkeの計算結果および, Freymuth6)と八木のデータを併せて示している. 実験 結果は彼らのデータとほほ一致しており, 擾乱が不 安定となることが示された。

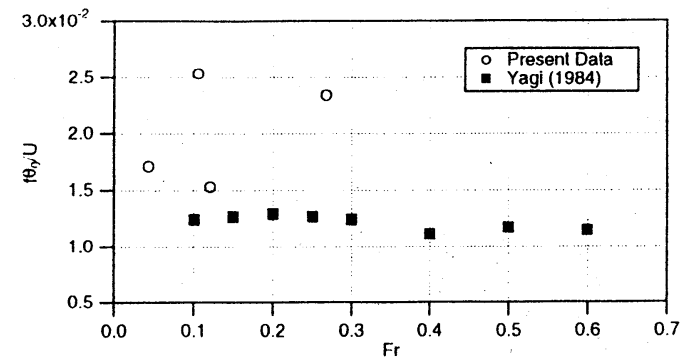

図-11 基本周波数 $f$ とフルード数の関係

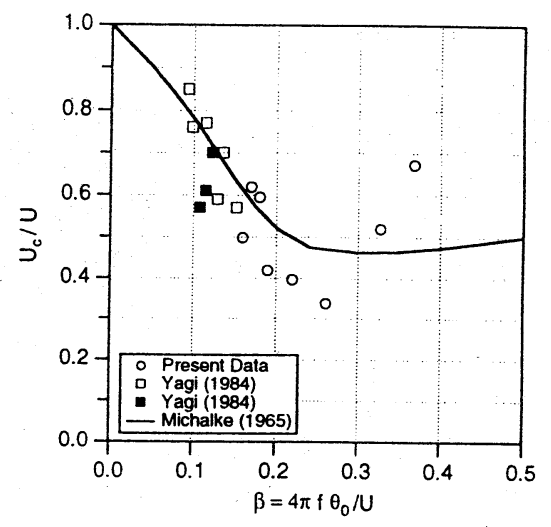

図-13 位相速度 $U_{c}$ と基本周波数 $f$ の関係

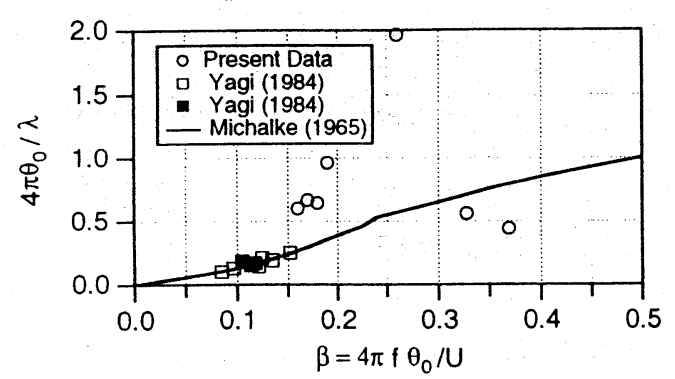

図-12 波数と基本周波数 $\mathrm{f}$ の関係

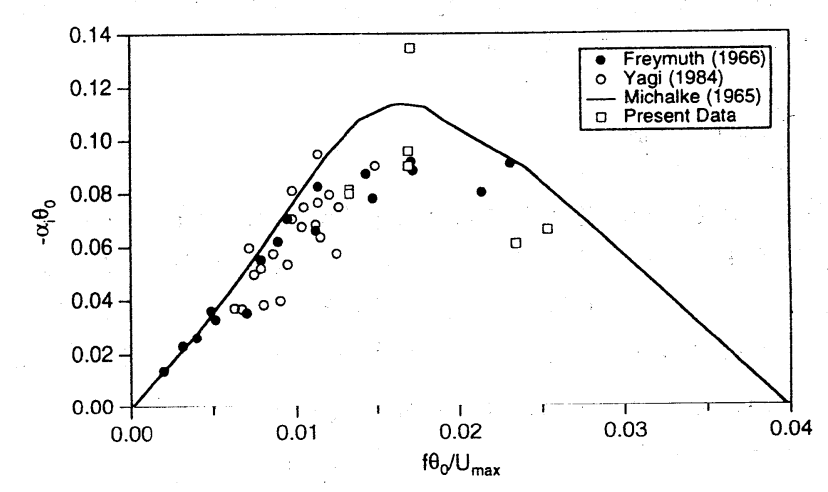

図-14 擾乱の空間的成長率 $-\alpha_{\imath}$ と基本周波数 $f$ の関係

\section{4.おわりに}

本研究では, 凹部長さ, 流量等を系統的 に変化させ開水路キャビティー流れの乱 流構造および渦の発生機構についての検 討を行った。しかし，不安定解析におい ては，凹部長さ，流量等を変化させた実 験データはまだまだ少ないため, 今の段 階では結論を出すことは難しい. そのた め, 今後さらなるデータの集積が必要で あると思われる。

\section{参考文献}

1) Knisely, C. and Rockwll, D. : J. Fluid Mech., vol.116, pp.157-186, 1982.

2) 八木俊策 : 凹凸流路における水質伝播に関する基礎的研究, 京都大学学位論文 1984.

3) 藤田一郎, 神田徹, 門脇正夫, 海津利幸 : 第26回乱流シンポジウム 講演会論文集, pp.96-99, 1994.

4) Nakagawa, H. and Nezu, I. : J.Hydr. Res., IAHR, vol.25, no. 1, pp.67-68, 1987

5) Michalke, A. : On spatially growing disturbances in an inviscid shear layer, J. Fluid Mech., vol.23, part 3, pp.521544, 1965.

6) Freymuth, P. : On transition in a separated laminar boundary layer, J. Fluid Mech., vol.25, pp.683-704, 1966 